\title{
Aile İşletmelerinde Büyüme Stratejisi olarak Uluslararasılaşma Seçeneği: Nitel Bir Araştırma

\author{
(Internationalization Option as a Growth Strategy in Family Businesses: A Qualitative
} Research)
}

\author{
Umut Sanem ÇiTÇi iD a Tuğba ONUR iD b \\ a Bakırçay Üniversitesi, İktisadi ve İdari Bilimler Fakültesi, İşletme Bölümü, İzmir, Türkiye. umutsanem.citci@bakircay.edu.tr. \\ b İstanbul Üniversitesi, Sosyal Bilimler Enstitüsü, İşletme Yönetimi ve Organizasyon Anabilim Dalı, İstanbul, Türkiye. \\ tugbaonur@ogr.iu.edu.tr
}

\begin{tabular}{|c|c|}
\hline MAKALE BİLGİSİ & ÖZET \\
\hline $\begin{array}{l}\text { Anahtar Kelimeler: } \\
\text { Aile işletmesi } \\
\text { Büyüme } \\
\text { Uluslararasılaşma }\end{array}$ & $\begin{array}{l}\text { Amaç - Bu çalışma, aile işletmelerinde büyüme stratejisi olarak uluslararasılaşmanın alternatif bir } \\
\text { yöntem olarak nasıl değerlendirildiğini belirlemek amacıyla yürütülmüştür. Literatürde, aile } \\
\text { işletmeleri için büyüme stratejisi olarak uluslararasılaşma seçeneğini araştıran bir çalışma henüz } \\
\text { yapılmamı̧tır. Bu boşluğa dayanarak, araştırma yerel ve uluslararası düzeyde faaliyet gösteren aile } \\
\text { işletmeleri üzerinde gerçekleştirilmiştir. }\end{array}$ \\
\hline $\begin{array}{l}\text { Gönderilme Tarihi } 10 \text { Kasım } \\
2019\end{array}$ & $\begin{array}{l}\text { Yöntem - Araştırma nitel bir çalışma olarak tasarlanmıştır. Bu amaçla, "aile işletmesi kimliği", } \\
\text { "büyüme" ve "uluslararasılaşma stratejilerini" değerlendirmek için yarı yapılandırılmış görüşme } \\
\text { süreci uygulanarak } 14 \text { aile şirketi temsilcisi ile görüşülmüşsürr. Elde edilen veriler nitel içerik analizi } \\
\text { uygulanarak analiz edilmiştir. }\end{array}$ \\
\hline $\begin{array}{l}\text { Revizyon Tarihi } 28 \text { Ocak } 2020 \\
\text { Kabul Tarihi } 9 \text { Şubat } 2020\end{array}$ & $\begin{array}{l}\text { Bulgular - Bulgularımız, "aile şirketi kimliğinin" tüm dezavantajlarına rağmen korunduğunu } \\
\text { ortaya koymuştur. Ayrıca, büyümede uluslararasılaşma firmanın yerel mi yoksa uluslararası } \\
\text { düzeyde mi çalıştığından bağımsız olarak, ayrıcalıklı bir büyüme stratejisi olarak } \\
\text { düşünülmemektedir. }\end{array}$ \\
\hline $\begin{array}{l}\text { Makale Kategorisi: } \\
\text { Araştırma Makalesi }\end{array}$ & $\begin{array}{l}\text { Tartışma - Sonuç olarak, uluslararasılaşmanın aile işletmelerinin büyüme kararlarında önemli bir } \\
\text { seçenek olarak görülmediği ve tüm yönetsel çabalarının aile şirketi olmanın getirdiği sorunların } \\
\text { çözümüne yönelik olduğu görülmüştür. }\end{array}$ \\
\hline
\end{tabular}

\begin{tabular}{ll}
\hline ARTICLE INFO & ABSTRACT \\
\hline $\begin{array}{l}\text { Keywords: } \\
\text { Family business }\end{array}$ & $\begin{array}{l}\text { Purpose - This study was conducted to determine how internationalization is considered as an } \\
\text { alternative method of growth strategy in family businesses. In the literature, a study that explores } \\
\text { the option of internationalization as a growth strategy for family businesses has not yet been } \\
\text { conducted. Based on this gap, this research was carried out on family businesses that operate in } \\
\text { lnternationalization }\end{array}$ \\
$\begin{array}{l}\text { Qualitative content analysis } \\
\text { Design/methodology/approach - This study was conducted as a qualitative research. For this } \\
\text { purpose, 14 family businesses representatives were interviewed by applying a semi-structured }\end{array}$ \\
$\begin{array}{l}\text { Received 10 November 2019 } \\
\text { interview process in order to evaluate "family business identity", "growth", and }\end{array}$ \\
"internationalization strategies". The data was analyzed by applying a qualitative content analysis. \\
Accepted 9 February 2020 & $\begin{array}{l}\text { Findings - Our findings suggested that "family business identity" was protected despite all the } \\
\text { disadvantages. Moreover, internationalization in growth was not consider a privileged growth } \\
\text { strategy regardless of whether the firm operating at local or international levels. }\end{array}$ \\
Article Classification: & $\begin{array}{l}\text { Discussion-After all, it was seen that internationalization was not considered as a significant option } \\
\text { in the growth decision of family businesses and all managerial efforts were still directed towards }\end{array}$ \\
Research Article & solving the problems of being a family business.
\end{tabular}




\section{Giriş}

Dünyada olduğu gibi Türkiye'de de şirketlerin yüzde 95'i KOBİ ve bunların da \%99'u aile işletmesi niteliğindedir (kobi.org.tr,2018). Bu kritik pozisyonu ve ekonominin bel kemiği olması bakımından aile işletmeleri üzerine sürdürülebilirlik (Karpuzoğlu,2004; Fındıkçı,2005); yönetimde kuşak çatışmaları (Erdoğmuş,2007; Aslan ve Çınar,2010); finansal problemler ve nepotizm (Ağca ve Kandemir,2008; Kutlu ve Demirci,2007; Uluyol,2004; Asunakutlu ve Avc1,2010; Dökümbilek,2010); kurumsallaşma (Yazıcıŏlu ve Koç,2009; Ulukan,2005; Özler ve Gümüştekin,2007) gibi çeşitli konularda pek çok araştırma yapılmaktadır. Ancak bu çalışma alanları içinde ulusal literatürde büyüme kavramına ilişkin yürütülen kapsamlı bir araştırmaya ulaşılamamıştır. Oysaki ülkelerin dünya ekonomisinde yer bulabilmeleri, kendi ekonomilerinin bel kemiğini oluşturan KOBI'lere, çoğunlukla da aile işletmesi niteliği gösteren bu ekonomik birimlere bağlıdır. KOBİ'lerle ilgili geliştirilen teorilerin genelde işletme büyüklügü ve pazar payı gibi belirli faktörlere önem verdikleri görülmektedir (Zaridis ve Mousiolis,2014: 463). Teorilerin yer verdiği büyüme kavramı yönetim alanında stratejik bir noktayı temsil etmektedir. Büyüme stratejisinde farklı seçeneklerden bahsedilmekle birlikte pazarı genişletmek noktasında uluslararasılaşma da bir seçenek olarak değerlendirilmektedir (Sapienza vd.,2006; Morgan ve Quack,2005; Lu ve Beamish,2006).

$\mathrm{Bu}$ çalışmada da aile işletmelerinde, büyüme ve uluslararasılaşma kavramlarının ne anlama geldiği, aralarında nasıl bir ilişki kurulduğu belirlenmek istenmektedir. Özelikle ulusal ve uluslararası literatürde sıklıkla vurgulanan "geçmişe göre daha kolay ve hızlı olan" uluslararasılaşmanın aile işletmeleri için de büyümede stratejik bir seçenek olarak konumlandırılıp konumlandırılmadığını anlama imkânı yakalanacaktır.

\section{Literatür Taraması}

\section{Aile İşletmelerinin Tanımı ve Kapsamı}

Aile işletmeleri, eski zaman ekonomilerinin ve medeniyetlerinin omurgası olarak hizmet vermelerinin (Atilla, 2016) yanı sıra günümüz ekonomisinin de temel ekonomik aktörleri olarak 60'lardan bu yana özel bir çalışma alanı olarak kabul görmektedir. Uzun zamandır var olmalarına, önem atfedilmesine ve üzerine pek çok araştırma yapılmasına rağmen "aile işletmesinin" ne olduğuna dair üzerinde mutabık kalınan bir tanımın olmadığ görülmektedir. ${ }^{1}$

Uluslararası literatürde aile işletmesine dair genelde ya yönetimin kimin elinde olduğuna (Gallo ve Sveen,1991) ya da mülkiyetin ve kontrol yetkisinin kime ait olduğuna (Bernard,1975; Alcorn,1982; Barnes ve Hershon,1976, Rosenblatt vd.,1985; Stern,1986, Leach vd.,1990) odaklanmış tanımların yapıldığı görülmektedir. Ulusal literatürde ise aile işletmeleri ile ilgili yapılan tanımlarda genelde "mülkiyet ve yönetim" ile "çalışanların kan bağı" ile bağlı olmasına odaklanıldığı tespit edilmiştir (Atilla,2016: 32). Tanım konusunda son nokta olmasa da çalışmanın devamını inşa edebilmek için yazarlar aile işletmesinin tanımını şu şekilde kabul etmişlerdir: Aile işletmeleri; "en az iki kuşağın doğrudan ya da dolaylı olarak yer aldığı, ailenin çıkar ve hedefleri doğrultusunda tek bir kişi, ki genellikle girişimcinin kendisi tarafından yönetilen, işletme ile ilgili karar ve planların aile tarafından yapıldığı ve özellikle de ailenin finansal konularda üstün söz hakkının olduğu işletmelerdir" (Karpuzoğlu,2002: 18; Atilla,2016: 33; Peşkircioğlu,2014; Ankara Sanayi Odası,2005: 15).

\section{Büyüme ve Uluslararasılaşma}

İşletmelerde büyüme "firmanın başarısının da bir kaynağı olarak sürekliliğini sağlaması ve nesiller boyu zenginliğini devam ettirebilmesi" olarak tanımlanmaktadır (Stenholm vd.,2016). Ulusal literatürde de Koçel (1993:9)' in “belirli bir ölçekteki işlemenin yapısını oluşturan maddi ve beşerî unsurlarında zamanla meydana gelen nitel ve nicel değişiklikler ve gelişmeler" olarak tanımladığı görülmektedir. Firmaları büyümeye iten şeyler ise pazardaki dinamizm, belirsizlik ve öngörülemeyen değişikliklere dair beklentilerdir (Stenholm vd.,2016). Genel olarak büyüme kavramına pozitif bir anlam yüklediği ve başarılı bir işletme olmanın boyutlarında biri olarak değerlendirildiği söylenebilir.

\footnotetext{
${ }^{1}$ Ekler kısmında 1960'lardan günümüze çeşitli çalışmalarda yapılan aile işletmesi tanımlarının yer aldığı detaylı bir tablo yer almaktadır.
} 


\section{U. S. Çitçi - T. Onur 12/1 (2020) 332-348}

Firmalar, tanımları gereği büyüme eğilimindedirler ve büyüme stratejileri de bu nedenle Stratejik Yönetimin önemli konularından birisidir (Rothaermel,2015:294). İşletmelerde büyüme üzerine çalışan önemli stratejistlerden biri de şüphesiz ki Igor Ansoff'tur. Ansoff (1957) çalışmasında, bir işletmenin nasıl büyüyebileceğini incelemiş ve birinci kuşak işletmelerde dört temel büyüme alternatifi sunduğu matrisi geliştirmiştir:

Tablo 1. Ansoff' un Büyüme Matrisi

\begin{tabular}{|c|c|c|}
\cline { 2 - 3 } \multicolumn{1}{c|}{} & Mevcut Ürünler & Yeni Ürünler \\
\hline Mevcut Pazarlar & Pazar Penetrasyonu & Ürün Geliştirme \\
\hline Yeni Pazarlar & Pazar Geliştirme & Ürün Çeşitlendirme \\
\hline
\end{tabular}

Kaynak: Ansoff (1957)

Pazar penetrasyonu, orijinal ürün-pazar stratejisinden ayrılmadan firma satışlarını artırma çabası içindedir. Firma, iş hacmini mevcut müşterilere satış hacmini artırarak büyümeye çalışmaktadır.

Pazar geliştirme, firmanın mevcut ürün yelpazesini (genellikle ürün özelliklerinde birtakım, ufak kabul edilebilecek değişikliklerle) yeni müşterilere uyarlamaya çalıştığı bir stratejidir.

Ürün geliştirme, firma mevcut pazarını muhafaza etmek birlikte üretim performansını artıracak yeni ve farklı özelliklere sahip ürünler geliştirme yoluna gider.

Ürün çeşitlendirme en gelişmiş alternatiftir çünkü firma hem mevcut ürün hattında hem de pazarlarında değişikliğe giderek performans artışını hedefler ve böylelikle büyümeye gider.

Yukarıdaki stratejilerin her biri, bir işletmenin büyüme stratejisinde izleyebileceği farklı bir seçeneği tanımlamaktadır. Ansoff (1957) bazı durumlarda bir işletmenin aynı anda birkaç seçeneği aynı anda tercih edebileceğini de ileri sürmüştür.

Aile işletmelerinin genelde KOBİ niteliğinde olması, büyüme konusunu alanda önemli kılmaktadır. Ancak bu önemine rağmen henüz aile işletmelerinde büyüme kavramını kapsamlı şekilde ortaya koyan bir açıklama setine rastlanmamaktadır. Aile işletmeleri perspektifinden büyüme kavramına bakıldığında aile üyelerinin büyüme motivasyonunun ardında pazardaki konumlarını sürdürmek ve pazarda büyük olmanın getireceği güç ve istikrarı yakalamak olacağı görülmektedir (Ulukan,1999).

Uluslararasılaşma kavramına geldiğimizde literatürde "uluslararası olma süreci için işletme faaliyetlerinin sınırlar arası gerçekleşmesini karşılayan bir kavram" olduğu görülmektedir. Günümüz dünyasında, ulusal sınırlar arasında işle ilgili faaliyetlerin sayısı artmıştır ve işletmeler yurtdışında geniş bir işlevsel entegrasyon alanı elde etmişlerdir (Azuayi,2016). Uluslararasılaşma, dünyada farklı büyüklükteki firmalar tarafından hızla benimsenmiş ve ülkeler arasındaki ticaret engellerinin kaldırılmasıyla daha da kolaylaştırılmış bir süreç haline gelmiştir.

Ekonomik düzenin küreselleşmesi ile birlikte yerel ekonomileri tedarik, üretim, satış ve satış sonrası hizmetler gibi işletme faaliyetlerinde birbirine daha bağımlı olduğu bilinmektedir (Fernández ve Nieto,2005). İşletmelerin birçoğu daha büyük bir pazara erişmek, ölçek ekonomisine ulaşmak, risk çeşitlendirmesi veya sadece rekabetçi dezavantajlardan kaçınmak amaciyla uluslararasılaşmaya gitmektedir (Gallo ve Sveen,1991) çünkü büyüme seçeneği sadece iç pazarla sınırlı değildir (Coşkun ve Sancaktutan,2019). Ancak, uluslararasılaşma her zaman avantajlı durumlar yaratmamaktadır. Özellikle de aile işletmelerinde aileye ait projelerin uluslararası rakiplere kaptırma ihtimali artırmasının yanında iş üzerindeki kontrol yetkisini de kaybetme riskini içermektedir (Okoroafo,1999) ki bu durum aile işletmelerinin uluslararasılaşmaya daha temkinli yaklaşmalarına neden olmaktadır (Coad,2009:111). Bu temkinli yaklaşımın ardında uluslararasılaşmanın gerektirdiği sermaye eksiliği, yöneticilerin uluslararasılaşmanın getireceği değişime karşı dirençleri, aile üyelerinin çeşitli gerekçelerle çatışma içinde olması (özellikle farklı hedef, değer ve amaçların varlığı vb.) gibi içsel/ aile işletmesi olmasından kaynaklı yapısal nedenler de sayılabilir (Ward,1997). Uluslararasılaşma konusunda yavaş hareket etmelerinin bir nedeni de şüphesiz ki küçük ve orta ölçekteki aile 
işletmelerinin uluslararası pazarlara açılma kararının ardından, iç pazardaki büyüme zorluklarının çok daha fazlası ile karşı karşıya gelebilecek olduklarına dair geliştirdikleri algıdır (Gallo ve García-Pont,1996).

\section{Araştırma Süreci}

Araştırmacılar yapmış oldukları literatür taramasından hareketle aile işletmelerinin büyüme ve uluslararasılaşma süreçleri arasında nasıl bir bağ olduğunu merak etmişlerdir. Aile işletmeleri için büyüme stratejisinin önemi nedir? Büyüme stratejisi olarak uluslararasılaşma bir seçenek olarak değerlendiriliyor mu? Büyüme ve uluslararasılaşma arasındaki ilişki yerel ve uluslararası düzeyde faaliyet gösteren işletmeler bakımından bir farklılık göstermekte midir? sorularına yanıt bulmak için bu araştırma gerçekleştirilmiştir.

Araştırma için nitel araştırma kurgusu uygun bulunmuştur çünkü nitel araştırmalarda insanların davranışlarını nasıl anlamlandırdıklarıyla ilgili bir anlayış geliştirmek ve deneyimlerini nasıl yorumladıklarını tarif etmektir esastır (Patton, 2014:33; Merriam, 2015: 14). Toplumsal hayatta bireyler kendi bağlamlarında bazı deneyimlere sahip olurlar ve bu deneyimleri kendi anlamlandırma süreçlerinden geçirerek paylaşabilirler (Merriam, 2015: 5). Araştırmacıların çalışmadaki amacının da büyüme ve uluslararasılaşma kavramlarına, aile işletmesi olmanın getirdiği bağlamsan farkı da ortaya çıkaracak şekilde nasıl yaklaşıldığı ve eylemlerine nelerin etkisinin olduğunu tespit etmek olduğu için nitel yöntem son derece uygun bir araç olarak kabul edilmiştir.

Nitel araştırma tasarımında iki farklı yol izlenebilir. Araştırmacının kendisi için belirlediği araştırma alanı daha önce oldukça çalışılan ve kavramlar bakımından gelişmiş bir alan ise bu durumda araştırmacı temalar düzeyinde detaylandırılmış sorular ile veri toplar ve analiz eder. Ancak literatür bakımından henüz yeni yeni gelişen, kavramların zenginliği bakımından kısıtları olan araştırmacılar ise tematik niteliği olmayan, genel sorular ile veri toplama yoluna gider ve bunları daha sonra analiz eder ve temalar geliştir. Bu çalışmada her ne kadar aile işletmeleri özelinde büyüme ve uluslararasılaşma stratejilerine ilişkin zengin bir kaynak setine ulaşılamamış olsa da genel olarak işletme yazınında bu kavramların ele alındığı bilinmektedir. Bu nedenle araştırmacılar literatür taramasından hareketle oluşturdukları temalar üzerinden mülakat soru setini geliştirmişler ve veri toplamışlardır.

Nitel araştırmalarda "olasılığa dayalı" örneklemden ziyade daha çok kasti/ amaçlı örneklem kullanılmaktadır (Punch, 2016: 183). Böylece araştırmacı, araştırma sorusuna cevap vereceğini tahmin ettiği en uygun nitelikteki katılımcıların dâhil edildiği bir örneklem üzerinde çalışma imkanı bulur. Bu araştırmada da araştırmacılar aile işletmesi olmanın ön koşulu olarak kan bağı ile birbirine bağlı en az iki kuşak bir arada çalışan ya da ilk kuşaktan birincil derecede akraba olanlarca yönetilen, yerel ve uluslararası düzeyde faaliyet gösteren ve olabildiğince farklı sektörlerde hizmet gösteren firmalar olmalarına özen gösterilmiştir. Firmaları belirlemek adına Sakarya OSB ( Organize Sanayi Bölgesi), Hendek OSB, Ferizli OSB ve Söğütlü OSB'nin internet sitelerinden yararlanarak firmalardan görüşme talebinde bulunulmuştur. Ancak firmaların ilgisizliği nedeniyle kişisel bağlantılar kullanılarak 7'si yerel, 7'si yerel ve uluslararası düzeyde faaliyet gösteren toplam 14 firma ile görüşme yapılmıştır.

Tablo 2. Görüşme yapılan firmaların (firma künyesi, görüşme tarihi, görüşmeci bilgisi)

\begin{tabular}{|c|c|c|c|c|l|}
\hline Firma Kodu & $\begin{array}{c}\text { Kuruluş } \\
\text { Y1lı }\end{array}$ & Sektör & Pazarı & $\begin{array}{c}\text { Görüşme } \\
\text { Tarihi }\end{array}$ & \multicolumn{1}{|c|}{ Görüşmeci } \\
\hline Y1 & 1923 & Gıda & Yerel & 28.09 .2018 & Üçüncü Kuşak \\
\hline Y2 & 1925 & Gıda & Yerel & 06.10 .2018 & Üçüncü Kuşak \\
\hline Y3 & 1954 & Çelik & Yerel & 25.09 .2018 & İkinci Kuşak \\
\hline Y4 & 1968 & Gida & Yerel & 04.09 .2018 & Üçüncü Kuşak \\
\hline Y5 & 1980 & İnşaat & Yerel & 09.10 .2018 & İkinci Kuşak \\
\hline
\end{tabular}


U. S. Çitçi - T. Onur 12/1 (2020) 332-348

\begin{tabular}{|c|c|c|c|c|c|}
\hline Y6 & 1989 & Kerestecilik & Yerel & 19.09 .2018 & Birinci Kuşak \\
\hline Y7 & 2016 & Süs Bitkiciliği & Yerel & 10.08 .2018 & İkinci Kuşak \\
\hline U1 & 1950 & Makine & Uluslararası & 26.09 .2018 & Üçüncü Kuşak \\
\hline U2 & 1974 & G1da & Uluslararası & 13.09 .2018 & İkinci Kuşak \\
\hline U3 & 1978 & Makine & Uluslararası & 24.09 .2018 & İkinci Kuşak \\
\hline U4 & 1985 & Makine & Uluslararası & 26.09 .2018 & İkinci Kuşak \\
\hline U5 & 1988 & Mobilya & Uluslararası & 28.09 .2018 & İkinci Kuşak \\
\hline U6 & 1995 & Makine & Uluslararası & 27.09 .2018 & İkinci Kuşak \\
\hline U7 & 2006 & Süs Bitkiciliği & Uluslararası & 10.08 .2018 & İkinci Kuşak \\
\hline
\end{tabular}

Nitel araştırmalarda analiz süreci veri toplama aşamasında başlamaktadır (Yıldırım ve Şimşek, 2018: 244). Bu çalışmada da araştırmacılar tamamlanan her görüşme sonrasında transkripsiyon işlemini gerçekleştirmiş ve veriler üzerinde, temalar bazında hazırladıkları kodlar ile kodlama sürecini başlatmışlardır. Söz konusu kodlama sürecini araştırmacılar ayrı ayrı gerçekleştirmiş ve daha sonra yaptıkları uzlaşı toplantılarında kod atamaları konusunda ortak karar geliştirmişlerdir. Ancak analiz esnasında araştırmacıların literatür temelli hazırladıkları temaların altında kod olarak öngörmedikleri fakat katılımcıların ifadelerinden yeni kod üretmeyi gerektiren cevaplar olmuştur. Bu durumda da araştırmacılar analizde in vivo kod kullanmışlardır. Yani görüşmeler sırasında katılımcının söylemiş olduğu bir ifade doğrudan bir kod olarak kullanılmıştır. Araştırmacılar kodlanan verilerin bir haritasını çıkartmak için MAXQDA 2018 paket programını kullanarak verilerin görsel olarak temsilini de sağlamışlardır.

Araştırmada durumun tespit edilmek istendiği 3 soru bulunmaktadır:

1. Aile işletmelerinde büyüme bir strateji olarak gündem oluşturuyor mu?

2. Büyüme onlar için bir strateji ise bu stratejinin gerçekleşmesinde uluslararasılaşma bir seçenek olarak değerlendiriliyor mu?

3. Büyüme ve uluslararasılaşma arasındaki ilişki yerel ve uluslararası düzeyde faaliyet gösteren işletmeler bakımından bir farklılık yakalamamıza imkan verir nitelikte mi?

Bu soruların her biri hem mülakat sorularının hazırlanmasında hem de analizinde temaların belirlenmesinde araç olarak kullanılmıştır ve tema-kod dağılımı şu şekilde belirlenmiştir:

- Aile işletmesi teması: Bu temanın oluşturulma nedeni araştırmada henüz hiçbir soru cevaplanmadan aile işletmesini temsilen görüşmeyi kabul eden katılımcının "aile işletmesi" olmayı nasıl değerlendirdiğini ortaya çıkarmaktır. Örnek kodlar; aile işletmesinin avantaj ve dezavantajları, kuruluşun amacı, kuşaklar, profesyonel ve aile üyesi ilişkisi vb.

- Büyüme ve fırsatlar teması: Bu temanın oluşturulma nedeni de katılımciların büyüme kavramına nasıl bir anlam yüklediklerini açığa çıkarmaktır. Büyümenin bir aile işletmesi için gerekli olup olmadığı, büyümenin nasıl mümkün olabileceği, büyüme için engellerin neler olduğu gibi soruların cevaplanması istenmiştir. Özellikle yerel düzeyde faaliyet gösteren firmaların büyüme kavramı üzerine konuşurken uluslararasılaşma kavramına değinmeleri ya da buna ilişkin yapacakları açıklamalar araştırma için hayati önem taşımaktadır. Örnek kodlar; pazar yapısı, büyüme algısı, büyüme stratejisi, dönüm noktası niteliğinde fırsatlar vb.

- Uluslararasılaşma süreci teması: Bu tema sadece uluslararası düzeyde faaliyet gösteren firmalar için kullanılmıştır. Çünkü hedeflenen şey uluslararasılaşmayı başaran firmaların bunu nasıl gerçekleştirdiğini ve yaptıkları işleri büyüme olarak görüp görmediklerini değerlendirmektir. Örnek kodlar; stratejik bilinç, uluslararasılaşma stratejileri, uluslararasılaşma engelleri vb. 


\section{Verilerin Analizi}

Araştırmacılarla görüşmeyi kabul eden aile işletmesi statüsündeki KOBİlerin temsilcilerine ilk olarak yerel ve uluslararası düzeyde işlemecilik faaliyeti yürütüp yürütmediklerine bakılmaksızın "aile işletmesinin kendileri için ne anlama geldiği" sorulmuştur. Kendilerinden beklenen şey aile işletmesinin doğrudan bir tanımını yapmaları değil, kendi bağlamlarında gelişen deneyimleri sonucunda aile işletmesi olmanın, bu tip bir işletme olarak piyasada var olmanın ne anlama geldiği, kuruluş amaçları, profesyonel yöneticiye bakış açıları, sürdürülebilirlik algıları, nepotizm üzerine açılamalar yapmalarıdır.

Görüşme yapılan aile işletmelerinin kuruluş nedenlerini para kazanmak olarak ifade ettiklerini; ancak yerel düzeyde faaliyet gösteren Y7 ile U4 ve U6 kodlu uluslararası düzeyde faaliyet gösteren firmaların ise para kazanmanın yanında topluma iyi hizmet sunmak olduğunu da belirttikleri görülmektedir. Diğerlerinden farklı olarak yine yerel düzeyde faaliyet gösteren Y7 ile uluslararası düzeyde faaliyet yürüten işletmelerden U7 ise çocuklarına iş imkânı sağlamak amacıyla kurulduğunu dile getirmiştir.

Aile işletmeleri literatüründe belki de en fazla bahsedilen sorunlarından biri olan kurumsallaşma da yine aile işletmesi kimliğinin anlaşılması üzerine sorulan sorulara cevap olarak gündeme getirilmiştir. Verilen cevaplardan bazı işletmelerin kendilerini kurumsallaşmış olarak değerlendirirken, ki bu durumu kendilerince belirledikleri kriterleri sağlamaktan yola çıkarak iddia etmektedirler; bazılarının da henüz beklenen düzeyde kurumsallaşmadıklarını bu nedenle yarı kurumsal olmak gibi bir ifade kullandıklarına şahit olunmuştur. Yarı kurumsal olma ifadesi daha önce araştırmacılar tarafından ön görülememiş bir koddur ve araştırmanın in vivo kodların birini teşkil etmektedir. Özellikle "kurumsallaşmamış/kurumsallaşamamış" ifadesini kullanmaktan çekindikleri gözlemlenmiştir.

Y4: "Tamamen profesyonel bir yaprya sahibiz. Ama aile olunca yarı kurumsal diyoruz."

Y1: “Zayıf olduğumuz yön profesyonel değiliz, güçlü yanımız da kalite tarafımız çok sağlam. Ama profesyonel değilim, duygusalım. Olması gereken bu, hikâyemin sürdürülebilir olmadığının da farkındayım. Ama ben böyle istiyorum. En azından ben kendi ömrümü böyle bitireceğim."

Y5: “...aile şirketi olarak kalmak, kurumsallaşma eğiliminde olmadan sadece yaptığımız işi en iyi yapma durumuna odaklanarak devam etmek var. Bizim müşteriler ile satış ve pazarlama da ilişkimiz direk ikili ilişkiye dayandı̆̆ı için kurumsallaşma ĕ̆iliminde değiliz."

Y6: "Şirketimizde 3 yıl önce başlayan bir kurumsallaşma çalışmamız var. Üniversite- IŞKUR- TÜBITTAK- SGK ortak çalışması ile şirketimizi nasıl kurumsallaştırırız bunun üzerinde çalışıyoruz. Çünkü Türkiye'nin \%98'i KOBI' lerden oluşan aile şirketleridir. Ne yazık aile şirketlerinin 3'ncü nesilde yok olma tehlikesi ile karşı karşıya olduğu için biz önden tedbir almak amaçlı kurumsallaşalım dedik. Üniversiteden 3 hocadan destek aldık. Onlarla birlikte çalışmalar yaparak şirketimizi kurumsallaştırma adına bu süreçte bütün hisseleri tek bir yerde topladık, diğerleri normal çalı̧̧an olarak devam ediyor. Kurumsallaşmanın son aşamasına geldik aile anayasasına kadar geldik, şimdi onun çalışması var, aile anayasası da bittikten sonra herkesin hisse paydalarına göre şirketimiz kurumsal olmuş olacak."

U5: “... yönetimde ismi geçen aile üyeleri olarak tam kurumsallaşmanın gerekliliğine inanmıyoruz. Ama kurumsallaşmamız gerektiğine de inanıyoruz. Bunun sebebi Türkiye'deki iş yapma sistemi, gerek bizim çalışı̆̆ımız müşteri portföyündekiler gerekse tedarikçilerimiz ile aradaki bir sünger görevindeyiz. Çünkü onu sıkıştırabilir ve açabilirsiniz de. Entegrasyonu sağlayan şeyin yeri geldiğinde küçülmesi yeri geldiğinde büyümesi gerekiyor. Bu yüzden esnekliğimizi korumamız gerekiyor. Kurumsallk bize esneklik vermez, daha çok bürokrasi doğurur. Kurumsallaşma için alışkanlıklardan vazgeçmek çok zor bunu yapmaya çalışıyoruz... Yarı kurumsal olmanın faydası..."

Yine literatürde aile işletmeleri için avantajlı durum olarak ifade edilen hızlı karar alabilmenin bu araştırmada desteklenmiştir. Ancak aile bağlarından dolayı kararların alınmasında aile içi hiyerarşiye bağlı olarak katılımın tam sağlanamadığından yakınıldığı tespit edilmiştir.

Y1: "Aile işletmesi olarak avantajımız hareket kabiliyetinin hızlı olması, tüm kararları çok çabuk hızl bir şekilde alabiliyorsun. Çok çabuk tepki verebiliyorsun. Karar mekanizması çok hızlı gelişiyor."

U7: “...mesela toplantı sırasında herkes görüşlerini belirtmiyor bazı şeyler kalıyor. Toplantı bittikten sonra mesela X hoşuna gitmeyen bir şeyi kendi bireysel olarak gidip yönetim kurulu başkanı ile görüşüyor. Ben bunlarn istemiyorum diyebiliyor. Ama onu toplantıda dile getirmiyor. Biraz iletişim problemimiz var. Bu akraba olduğumuzdan kaynaklanıyor." 


\section{U. S. Çitçi - T. Onur 12/1 (2020) 332-348}

Tespit edilen bir diğer dezavantaj nepotizm-adam kayırmacılıktır. Aile işletmelerinin temel sorunlarından biri olarak literatürde yer bulan bu başlık, araştırmacılar aile işletmesinin çalışanlarıyla değil de aile işletmesini temsil edebilecek kuşak temsilcileri ile görüşülmesinden dolayı doğrudan nepotizmin olduğuna ilişkin ifadeler kullanılmamıştır. Ancak şu söylenebilir ki yerel düzeyde faaliyetlerini yürüten aile işletmelerinin, uluslararası düzeyde faaliyet gösterenlere göre daha fazla tanıdık çalıştırma yatkınlığı bulunmaktadır.

Aile işletmelerinde yönetimin profesyonel bir yöneticiye devredilmesi işletmenin gelecek nesillere taşınması açısından önemli bir adımdır fakat işletme sahibi aile üyeleri için bazen bu durum çok zor olabilmektedir. Genel olarak yerel ve uluslararası düzeyde faaliyet gösteren aile işletmelerinde profesyonel yöneticiye bakış temasında olumsuz bir yaklaşımın olduğu görülmektedir. Ancak kurumsallaşmanın bir adımı olduğunu öne sürerek profesyonel yöneticiye olumlu yaklaşan firmalar da yok değildir. Olumsuz tarafta olan firmalar yıllardır emek verdikleri işletmelerini bir başkasına teslim etmede ve yabancı birinin onları yönetmesi konusunda çekimser davranmaktadır.

Y5: "1980'den beri yani 38 yıldır aile kuruluşu ve aile yönetiminde olan bir şirketi başka bir yöneticiye bırakamayız tabi ki. Bu bizim için evladımızı evlatlık vermekten farklı bir şey olmaz. Biz esnaf usulü çalş̧an bir firmayız kurumsal bir yapımız yok. Bu yüzden evladımızı (şirketi) bizden daha iyi tanıyan bir yönetici olamaz."

Y4: “Şimdi siz bu işletmeye elinizle tırnă̆ınız ve kurmuşsunuz sıfırdan 93 yılında tekrardan 2. kuruluşunu yapmışsınız. Günde 2200 litre süt ile başlamışsinız sonra 350 ton süte kadar çıkmıssınız. Sonra gelecek biri sizi yönetecek. Hayır, böyle bir şey olamaz bir danışman alırsınız."

Görüşmecilerin aile işletmesi kimliğine yükledikleri anlamları açığa çıkarma girişiminden sonra araştırmanın ana konusu olan büyüme ve uluslararasılaşma kavramlarına nasıl yaklaştıklarını anlamak üzere tematik sorulara geçilmiştir. Öncelikle hem yerel hem de uluslararası düzeyde faaliyet gösteren aile işletmelerine büyüme ve fırsatlar üzerine çeşitli sorular yöneltilmiştir. Yerel aile işletmelerinde ürün geliştirme üzerinden büyüme stratejisi izlendiği görülmektedir. Ancak yine yerel düzeyde çalışan Y3, Y4 ve Y5 işletmeleri ürün geliştirmenin yanında pazar penetrasyonunu da bir seçenek olarak görmektedirler. Uluslararası düzeyde faaliyet gösteren aile işletmelerinde ise ürün çeşitlendirmenin ağırlıklı olarak tercih edildiği görülmektedir.

Büyüme ve fırsatlar ile ilgili sorulara yanıt veren yerel düzeyde faaliyet gösteren aile işletmelerinin doğrudan uluslararasılaşma ile ilgili bir ifade kullanmadıklarını gören araştırmacılar, bu kez kendileri bir soru olarak "uluslararasılaşma büyümek için bir seçenek olabilir mi ?" diye bir soru yöneltmişlerdir. Bu soruya verilen cevaplarda uluslararasılaşmanın aile işletmesi olmaktan ve içinde yer alınan sektörden dolayı bazı avantaj ve dezavantajlar setine sahip olunduğu anlaşılmıştır. Yerel bir işletme olup uluslararasılaşmayı düşünen işletmeler uluslararası piyasaya açılarak dünyaya adlarını duyurabileceklerini, ülkede yaşanan ekonomik sıkıntıları atlatmak için bir alternatif olabileceğini ve yeni pazarlara ulaşarak büyüme imkanı yakalayacaklarını dile getirmişlerdir. Ancak aralarında uluslararasılaşmayı bir seçenek olarak hiç değerlendirmeye almayanlar aile işletmeleri de mevcuttur. Bu durumun gerekçesini ise bulundukları sektöre dayandırmaktadırlar.

Y1: "Firmamızın kalite yönünden çok fazla kuralı var. Onlar hep size pranga oluyor. Asla dediğgimiz bir sürü şey var. Üretimdeki hammaddelerimizi değiştirmemiz gerekiyor. O zaman asla kurallarınızı yıkmaya başlıyorsunuz. Bir kuralı yıktığınız da hepsini yıkılıyor. Mesela yaptığımız lokumun ömrü en fazla 3 ay ama uluslararası olması için bunun ömrünün en az 1 yıl olması lazım. O zaman başka şeyler başlıyor. Bir kereden bir şey olmaz derken önüne geçilemeyecek şeyler ortaya çıkıyor."

\section{Y4: "Uluslararasilaşma büyümenin bir yolu olabilir. Bizim sektör için bugün bu uygun değil."}

Uluslararası düzeyde faaliyet gösteren aile işletmelerinin ise tamamı uluslararası arenayı büyümede bir fırsat olarak değerlendirmektedir:

U1: "Ekonomik kriz bizi çok fazla vurmadı. Yurtdışında 24 ülkeye satış yapıyoruz."

U3: "Ama bizim tercihimiz uluslararası pazarlar çünkü kur ve malzemeye gelen zamlardan etkilenmemek için."

Çalışmanın oldukça ilginç bulgularından birisi de hem yerel ve hem de uluslararası aile işletmelerinin "büyüme" konusunda temkinli yaklaşım sergiliyor olmalarıdır. Hatta büyümenin ne anlama geldiği içinde bulunulan şartlarla ilişkilendirilerek açıklanmaktadır. Ülkenin içinde bulunduğu mevcut ekonomik koşullarda bir işletmenin halihazırdaki durumunu koruyabilmesinin bile büyüme olabileceğine dair 


\section{U. S. Çitçi - T. Onur 12/1 (2020) 332-348}

görüşmecilerin ifadeleri bulunmaktadır. Temkinli hareket etmeyi ise işletmelerin kredi almadan ellerinde olan varlıklar ile yatırım yapmaları olarak yorumlamaktadırlar. Görüşme yapılan sadece bir işletme temsilcisi büyüme için risk almak gerektiğini söylemiş ve büyüme ile risk arasında bir ilişki kurmuştur.

Y5: "Biz açıkçası çok büyüme derdinde değiliz, tabiri caizse daldan dala atlamıyoruz, büyümek kendi işimiz sektörümüz ile orantılı olarak."

Y6: "Yalnız hızlı büyüyen şirketlerdeki sorun balon büyüyor hızh batıyor. Büyümenin de bir ölçüsü var adım adım, altını doldura doldura büyürseniz yıkılmanız daha da zordur. Bizim hedefimiz çok büyümek değil. Çok büyüyüp de işçilerin maaşlarını aksatıyorsanız, vergi veremiyorsanız o büyüme değildir. Her birimin altını doldurarak, oradaki mali yapıyı bozmadan büyüyebiliyorsanı büyüme budur. Kaliteyi bozmuşsanı maliyetleri yükseltmişseniz bu büyüme olmuyor."

U4: "Şu zamanda kontrollü büyümenin doğru olduğunu düşünüyorum. O yüzden biraz daha yavaş yavaş gitmek gerekiyor. Bir anda yükselip de çok batan örnek gördüğ̈̈müz için bunu söylüyorum. Bunu ilk başta tezgâh alacaksin, eleman alacaksin derken gittikçe büyüyeceksin."

U5: "Şu an büyüme devri değil olduğun yeri koruma devri, olduğun yeri korursan büyümüş olursun."

Son olarak sadece uluslararası düzeyde faaliyet yürüten aile işletmelerine uluslararasılaşmayı nasıl gerçekleştirdikleri, buna nasıl karar verip nasıl bir yol izlediklerine dair sorular yöneltilmiştir. Bu soru grubunun sorulmasının bir nedeni de yine cevapların içinde büyüme ve uluslararasılaşma arasında bir ilişki kurulup kurulmadığını yakalayabilmektir.

Görüşme yapılan aile işletmelerinin 3 farklı şekilde uluslararası düzeyde faaliyete geçme imkânı yakaladığı görülmüştür. İlk grup kendi kararları ile bilinçli olarak kendilerine uluslararası pazar bulup hedefe dönük işler yapanlar; ikinci grup uluslararasılaşma konusunda isteği ülkenin yaşadığı sıkıntılı durumlardan sıyrılmak adına alternatif bir yol olarak bu işi yapanlar; son olarak da bilinçsizce uluslararası faaliyette bulunanlardır yani bu grup hiç aklında yokken bir vesile ile bir anda uluslararası işletmecilik faaliyetlerinde bulunanları içermektedir.

Bilinçli uluslararasılaşan işletmeler (U1,U6 ve U7) bu bilinci geliştirebilmelerini arkadan gelen kuşağın daha iyi eğitim almış olmasına ya da yönetime geçmiş olmasına bağlamaktadır. Ayrıca yerel pazarda rakip sayısının artması ile birlikte yaşanan daralmayı aşmak adına mevcut ürünlerine yeni pazar arayışı içine girdikleri de görülmektedir.

U7: "Onlardan 2 yıl sonra Dubai'de bir fidanlık kurduk. O bölgede savaş var ve o savaşlardan sonra kentleşme ve ister istemez peyzaj ihtiyacı ortaya çıkacak inşaat işleri artacak. Bu da bizim için öngörüde bulunarak yaptı̆̆ınız bir yatırım, bir strateji. 3-4 yıl önceden öngörerek hareket ettik. Bu yatırım şirketinizi \%30 büyüttü."

İkinci grupta U2 işletmesi piyasada yaşanan bir kriz neticesinde uluslararası pazara yönelmiştir.

U2: “Mesela bizim ihracat işimiz piyasanın akışına göre başladı. 2011 yılında Avrupa'da yoğun kar yağışı nedeniyle tuz stokları biten Almanya, Fransa bölgesindeki ülkelerin Türkiye'den talepte bulunması, o sene normalde almaları gereken Mısır'dı. Fakat Mısır'da da darbenin olmuş olması Arap baharının yaşandığı süreçlere rastlaması Türkiye için bir firsat oldu. Normalde Türkiye tuzu pahalıdır. Adamlar o kadar tuzsuz kaldı ki standart bile aramadılar. Yeter ki tuz yolla dediler. İhracatı hiç bilmeyen bizler o süre içerisinde öğrenmiş olduk. Ama iyi bir şey olduğunu ve yapılabilirliğini görünce ihracat yapmaya başladık."

Üçüncü grup olarak ifade edilen bilinçsiz olarak uluslararasılaşmayı başaran U4 işletmesi ise aslında Türkiye'deki bir işletme için ürün üretirken bir gün aslında ürünlerinin uluslararası arenada yer aldığını ama kendi adlarının geçmediğini fark etmesi sonucu uluslararasılaşmaya karar vermiştir.

U4: "Bir firma ile çalışıyorduk hala daha da devam ediyoruz. Onlara makine yapıyorduk ama logolarımızı basmıyorduk. Onlar logolarını basıp ülke içine ve dışında yolluyorlardı. Belki de bu bizim için dönüm noktası sayılabilir. Bir gün Alibaba'da sayfamı oluşturdum. Ama benim makinam çıkmıyor. Ama benim ürettiğim müşterimin logosunu bastığı ürün oradaydı. Ama benim adım yoktu, her ülkenin gördüğ̈̈ bir platformda."

Görüşme gerçekleştirilen uluslararası düzeyde faaliyet gösteren aile işletmelerin çoğunun ihracat yaptığı görülmektedir. İhracat yapma sürecinin nasıl gerçekleştiği sorulduğunda işletmelerin sosyal ağları, sosyal medyayı ve fuarları kullanarak bunu başardıkları tespit edilmiştir. Sadece U7 işletmesinin diğerlerinden farklı 


\section{U. S. Çitçi - T. Onur 12/1 (2020) 332-348}

olarak joint venture- ortak girişim ile yurtdışı pazarına girdiği ve bunu sahip olduğu siyasî bağlantılar ile gerçekleştirdiği görülmüştür.

Araştırmacılar son olarak uluslararası düzeyde faaliyet gösteren aile işletmelerine "diğer aile işletmelerinin niçin uluslararası faaliyetlerde bulunmadıklarını" sorarak onların gözünden gerekçeleri tespit etmek istemişlerdir. Gelen yanıtlar ülkedeki politik ve ekonomik alandaki yapısal engeller ile eğitim-bilgi eksikliğini içerecek şekilde olmuştur.

U6: "En büyük engel gümrük engeli, hatta birçok firma ile artık işin sonuna gelmişken bile gümrük masraflar ve işlemlerinden dolayı kaçırdığımız işler var. En büyük problem bu, prosedürlerin biraz daha kolay olması gerekiyor. Maliyetler, gönderim ücretlerinden dolayı."

U7: "Bazı engeller ile karşılaştık mesela bitkilerin bazılarında gümrükte sorun yaşıyoruz. Devlet prosedürleri sadece işleri zorlaşttriyor. Esneme yok. Mesela Türkmenistan'a bir eleman gönderecektik ama oradan mektup ile istek yollanması gerekiyormuş bunda bir sorun yaşadık."

U2: "Dış ticaret ile ilgili dil noktası sıkıntı, ben yüksek yapmama rağmen dil problemini çözemedim. Yurtdışına açıldığında dil lazım oluyor. Fransızcanın Afrika bölgesinde hâkim olduğunu gör. Biz hep İngilizce üzerinden hareket ettik bir dil bile yetmiyor bu noktada."

U4: "SATSO 'da bir dış ticaret eğitimine gitmiştim. Firma bulmak için çok kanal varmış ama biz bunları bilmiyorduk. Dış ticaret için eleman alımı yapıp bu eksiğimizi gidermek istiyoruz."

Aşağıda yer alan Şekil 1, Şekil 2 ve Şekil 3, MAXQDA 2018 nitel veri analiz paket programında araştırmacıların transkripsiyonları okurken temalar üzerinden geliştirdikleri kodların ataması ile ortaya çıkan kod haritasını sunmaktadır. Söz konusu haritalar yerel ve uluslararası düzeyde faaliyet gösteren KOBİler için ayrı ayrı çıkarılmıştır. Haritalamada dikkat edilmesi gereken şey kalın çizgilerdir çünkü bunlar görüşmelerde en sık tekrarlayan kodları vurgulanmaktadır. Kesikli çizgiler ise diğer kategori ve kodlar arasındaki ilişkileri göstermektedir. Bu haritalama araştırmacıların sonuç kısmını hazırlarken üzerinde özellikle durması ve yorumlamaları gereken noktaları göstermesi bakımından önemli bir araçtır.

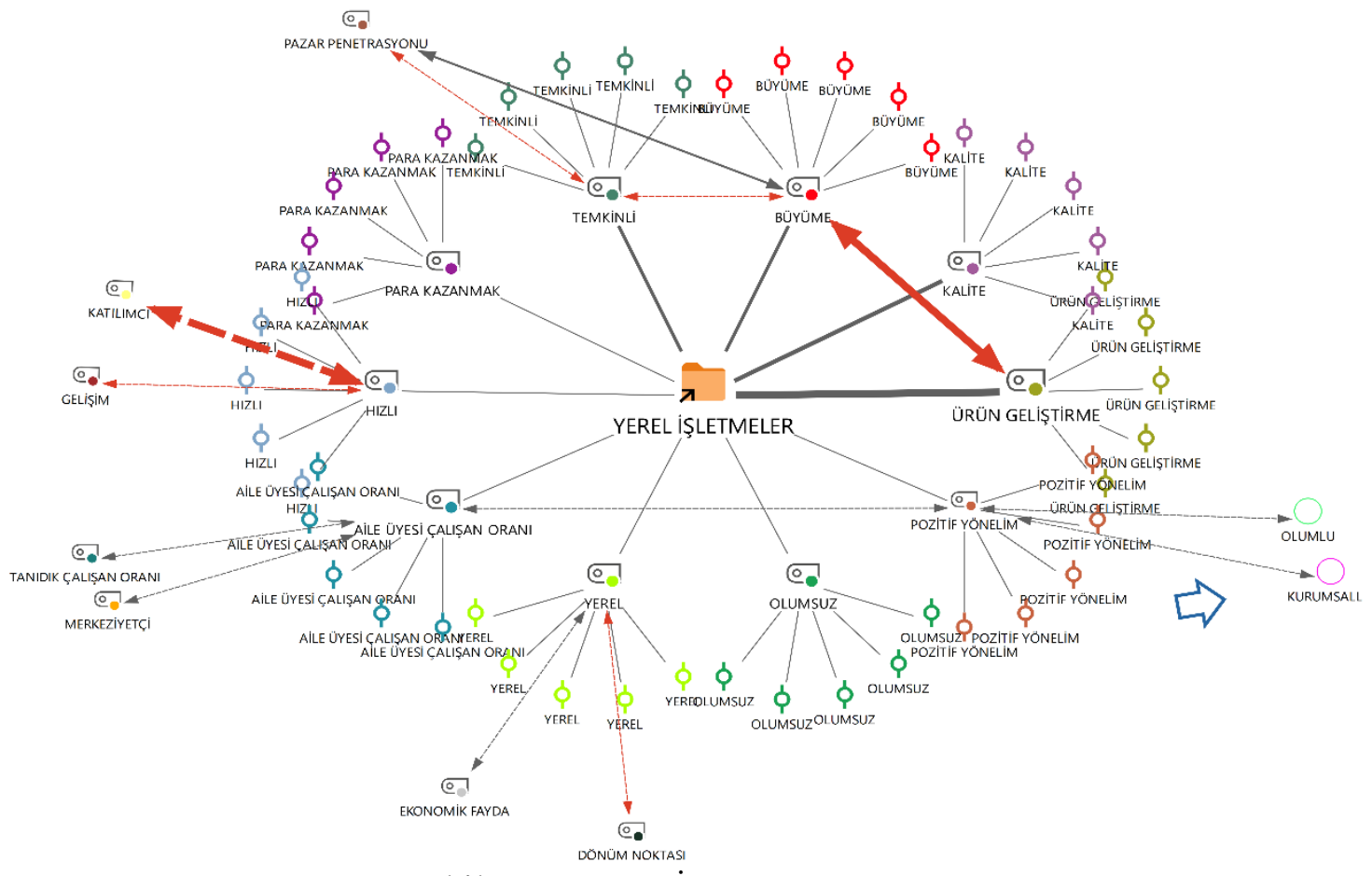

Şekil 1. Yerel Aile İşletmelerinin Görsel Haritası 


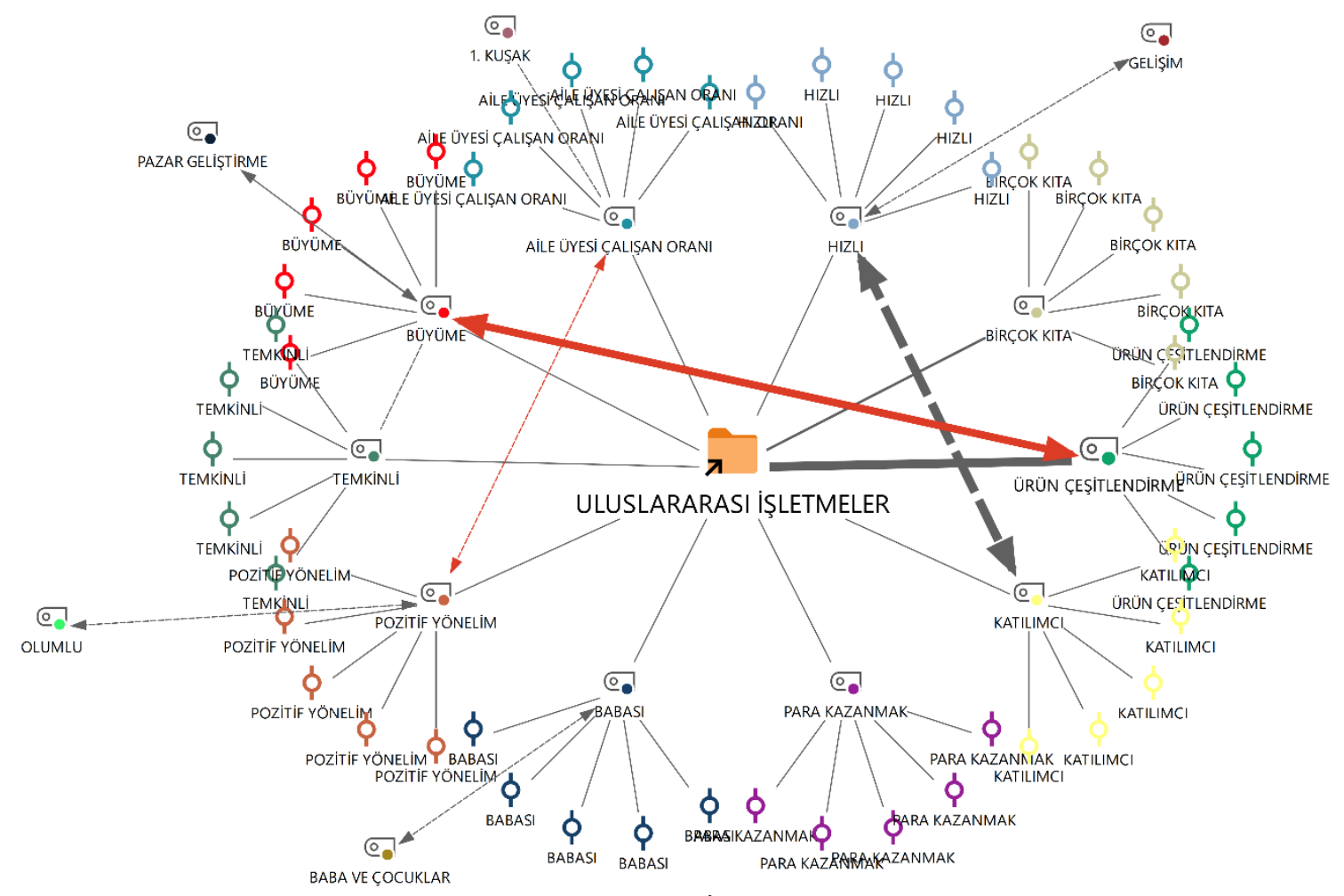

Şekil 2. Uluslararası Aile İşletmelerinin Görsel Haritası

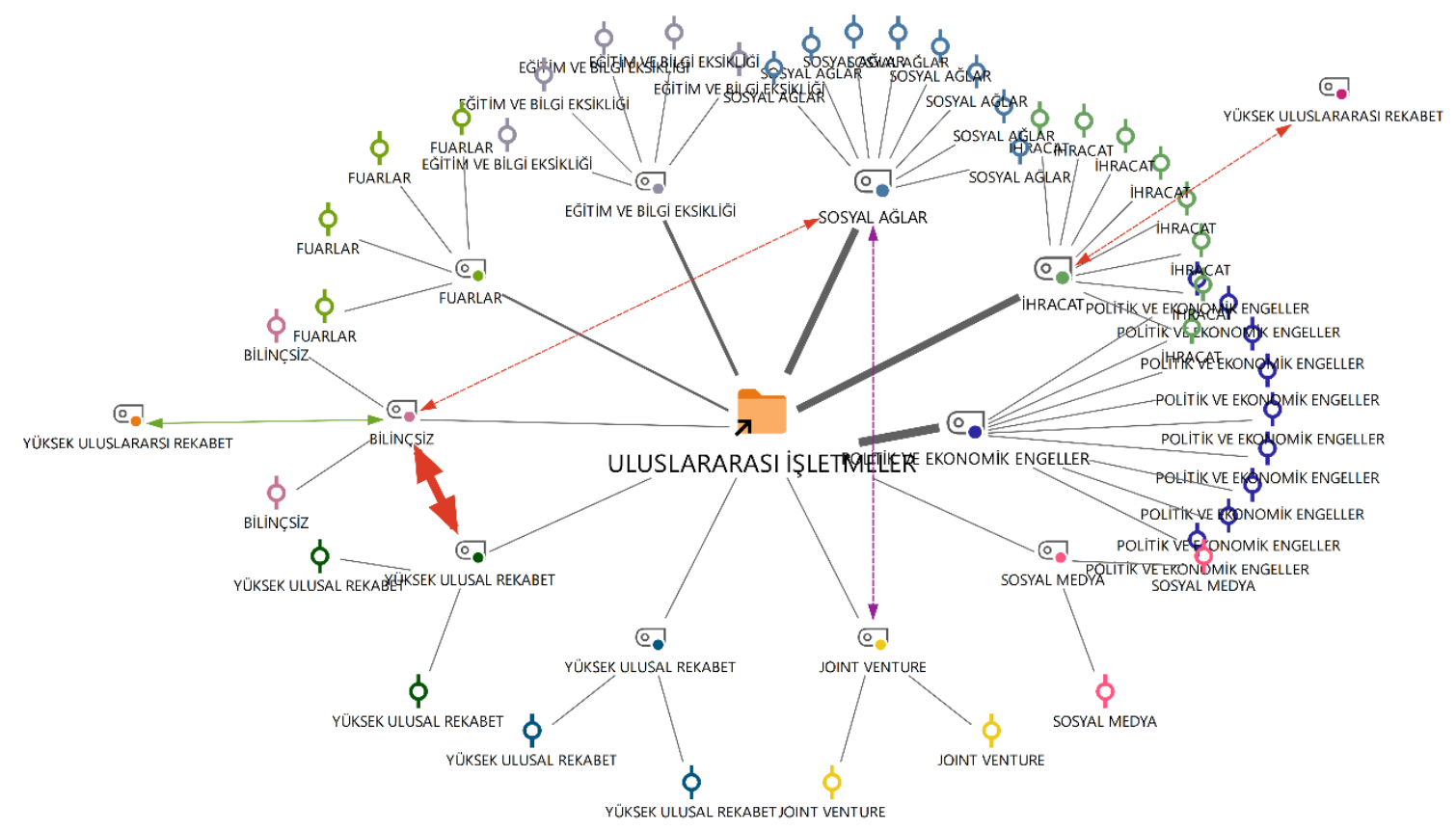

Şekil 3. Uluslararasılaşma Sürecinin Görsel Haritası

\section{Sonuç ve Gelecek Araştırmalar için Öneriler}

"Aile işletmelerinde büyüme stratejisi olarak uluslararasılaşma bir seçenek midir?" araştırma sorusuna yanıt bulmak üzere yürütülen bu araştırmada, araştırmacıların esas amacı nitel araştırmanın gereği olarak genelleme kaygısı ile değil deneyimsel temelli, bağlamın şekillendiriciliğinde mevcut durumun portresini belirlemektir.

14 aile işletmesinin temsilcileri ile gerçekleştirilen görüşmelerden edinilen veriler analiz edilmiş ve erişilen bulgular araştırmacılar tarafından aşağıdaki başlıklar altında yorumlanmıştır. 
Aile işletmesi kimliğinin getirileri

* Görüşmeciler piyasada aile işletmesi olmanın ne denli zor olduğundan bahsetseler de "aile işletmesi kimliğine" sahip çıkmaktadırlar ve bu durumu aşmak zorunda oldukları bir engel olarak görmediklerini dile getirmektedirler.

* Yukarıda bahsedilen aile işletmesi kimliğine bağlı olarak kurumsallaşma olgusuna da oldukça farklı yaklaşmaktadırlar. Kurumsal olmayı, literatürde bahsedilen kriterlerden farklı olarak kendilerince geliştirdikleri kriterler üzerinden değerlendirdikleri ve kendilerini "yarı kurumsallaşmış" olarak kabul ettikleri görülmektedir. Kurumsal olmama ya da kurumsallaşamama ifadelerinin hiç kullanılmamış olması (görüşmecilerin soruları yanıtlarken ki tavır ve ses tonlarından hareketle) bu kavramı kullanmanın güçlerine gittiği fikrini doğurmaktadır. Hatta bir görüşmeci "biz zaten kurumsal olmak istemiyoruz" demiştir. Yani bu başaramadığı bir şey değil, istemediği bir şeydir. Bu çalışmanın ana konusu aile işletmelerinde kurumsallaşma olmadığı için detaylandırılamayan bu durum ileriki çalışmalarda hususi olarak araştırılabilir.

* Aile işletmeleri literatüründe özellikle kendine yer bulan hızlı karar verme avantajının bu çalışmada görüşmecilerce de dile getirildiği görüşmüştür. Ancak kararların hızlı alınmasının nedeni bürokratik süreçlerin kısa olması değil, aile içi hiyerarşide üst düzeyde olan aile üyelerinin kararlarının herkes için kabul edilir olmasıdır. Yani karar sürecinde tartışmaya mahal vermeyen sadece ortak kararmış gibi onaylanan aile büyüğü kararı olması, aile işletmelerine hız kazandırmaktadır. Bu tespit literatürde pek çok çalışmanın varsayımı olan "kolay erişim, bürokratik süreçlerin yokluğu hızlı karar almayı doğurur" ifadesini sorgulamayı gerektirmektedir. Bunun için geniş bir örneklem kitlesi üzerinde özellikle de aile işletmelerinde çalışanların dahil edildiği bir örneklemde genelleyici bir araştırma yapmak uygun olabilir.

* Aile işletmesi kimliğinin bir getirisi de çalışanların genelde aile üyesi ya da tanıdığı olmasıdır. Bu durumun söz konusu araştırma örnekleminde yerel ve uluslararası düzeyde faaliyet gösteren işletmeler arasında farklı olduğu tespit edilmiştir. Uluslararası faaliyette bulunanların daha fazla bilgi ve beceri gerektiren işler içermesi, aile üyesi ya da tanış havuzunun dışından çalışan arayışına girmelerine neden olmaktadır. Bu durumda yine başka bir araştırmada daha büyük bir örneklemde test edilebilir hipotez haline getirilebilir.

* Aile işletmelerinin literatürde problemli alanlarından biri olarak değerlendirilen profesyonel yönetici çalıştırma durumunun bu araştırmada da yine yerel ve uluslararası düzeyde faaliyet göstermesine bakılmaksızın ciddi bir sorun haline getirildiği görülmektedir. Profesyonel yönetici çalıştırmanın travmatik bir hal almasının nedeni "işletmeyi evladı olarak görmek" olabilir. Bilindiği üzere Türk kültüründe "evlat acısı" yani evladı kaybetmek en büyük acı olarak değerlendirilmektedir. Bilhassa profesyonel yöneticinin işletmeyi aile üyeleri kadar sahiplenmeyeceği ve buna bağlı olarak yok edebilecek kararları daha rahat alacağı düşünüldüğü için profesyonel yöneticinin travmatik bir alan olarak daha uzun süre sorun olarak kalması muhtemeldir. Yine daha sonra yürütülecek bir araştırmada benzer ve farklı kültürel değerleri olan ülkeler arasında aile işletmelerinde profesyonel yöneticiler ve evlat olarak değerlendirilen örgütler üzerine bir araştırma yapılabilir.

*Aile işletmesi kimliğinin bir parçası olarak düşünülmesi nedeniyle firmanın niye kurulduğu sorusu da temsilcilere sorulmuştur. Yerel düzeyde faaliyet gösterenlerin para kazanmak ve ileride çocuklara iş imkanı yaratmak için kurulduğu vurgulanırken; uluslararası düzeyde faaliyet gösterenlerin ise para kazanmanın yanında topluma hizmet etmek gibi bir misyonunun da olduğu görülmektedir.

\section{Aile işletmelerinde bir strateji olarak büyüme}

*Aile işletmelerinde büyüme kavramına yüklenen anlam için Ansoff (1957)'un geliştirdiği matristen yararlanılmıştır. Bazı yerel düzeyde faaliyet gösteren aile işletmelerinin genelde pazar penetrasyonu ile mevcut ürünü mevcut pazarda ayakta tutmaya çalışırken, uluslararası düzeyde faaliyet gösteren işletmeler ile bazı yerel düzeyde faaliyet gösterenlerin ise yeni pazarlar ve yeni müşteri grupları için ürün geliştirmeye gittikleri görülmektedir. Bu durum beklentilerle uyumludur çünkü uluslararası faaliyette bulunmak isteyen işletmelerin farklı kültür, yaşam standartları ve farklı müşteri beklentilerini göze alıp yeni ürün geliştirme faaliyetleri üzerinden ürün gamındaki ve pazarında genişleme ile büyümesi normaldir. 


\section{U. S. Çitçi - T. Onur 12/1 (2020) 332-348}

* Büyüme kavramına bakış açısının gelişmesi şüphesiz ki aile işletmesinin içinde yer aldığı sektörün etkili olacağıdır. Özellikle gıda sektöründe faaliyet gösteren işletmelerin merkezde yakaladığı lezzeti ve standardı büyümenin getirdiği yayılım ile kaybetme korkusu bulunmaktadır.

Büyüme stratejisinde uluslararasılaşma seçeneği

* Aile işletmelerinin uluslararasılaşma becerisi kurucularının uluslararası vizyona sahip olmasına ya da arkadan gelen kuşakların uluslararasılaşmayı kolaylaştırıcı imkanları işletmeye getirmesine bağlı olabilir. Türkiye'de aile işletmelerinin niçin uluslararasılaşamadığı sorulduğunda yapısal problemlerin yanında özellikle eğitim ve bilgi eksikliği vurgusu da yine bu konuda destekleyici bir bulgudur.

* Aile işletmelerinin temsilcileri büyüme kavramı sorulduğunda doğrudan uluslararasılaşmayı bir seçenek olarak görmemiş, dile getirmemişlerdir. Bu durum uluslararasılaşmanın aile işletmelerinde bir büyüme stratejisi olarak doğrudan düşünülmediğinin bir kanıtı olarak kabul edilebilir. Araştırmacılar durumu netleştirmek adına uluslararasılaşan firmalara bunu nasıl gerçekleştirdiklerini sorduklarında bilinç düzeyinin farklılık göstermesi, kiminin bunu planlayarak kiminin ise şartların sonucunda yani itici bir güçle kiminin ise tamamen tesadüfle bunu gerçekleştirdiğini tespit etmişlerdir.

* Aile işletmelerinin uluslararasılaşma derecesinin genel de ihracat düzeyinde olduğu görülmekle birlikte bunun gerçekleştirmede sosyal ağlarından yararlandıkları görülmektedir Büyümeyi ürün çeşitlendirmesi ile sağlayıp, ürün çeşitlendirmesinin kendilerine sağladıkları avantaj ile uluslararasılaşmaktadırlar.

\section{Kaynakça}

Ağca, V. ve Kandemir, T. (2008). Aile İşletmelerinde İç Girişimcilik Finansal Performans İlişkisi: Afyonkarahisar'da Bir Araştırma. Sosyal Bilimler Dergisi, 10 (3), 210- 230.

Alcorn, P. B. (1982). Success and survival in the family-owned business, New York: McGraw-Hill.

Ankara Sanayi Odası (ASO) (2005). Aile Şirketleri: Değişiim ve Süreklilik. Haziran, Ankara.

Ansoff, H. I. (1957). Strategies for diversification. Harvard Business Review, 35 (5), 113- 124.

Aslan, İ. ve Çınar, O. (2010). Bir Aile Şirketinin Kurumsallaşması: Yeniden Yapılandırma Ve Varislerin Yönetime Hazırlanması Süreci. Organizasyon ve Yönetim Bilimleri Dergisi, 2 (1), 89- 97.

Asunakutlu, T. ve Avcı, U. (2010). Aile İşletmelerinde Nepotizm Algısı Ve İş Tatmini İlişkisi Üzerine Bir Araştırma. Süleyman Demirel Üniversitesi İktisadi ve İdari Bilimler Fakültesi Dergisi, 15 (2), 93-109.

Atilla, İ. (2016). Aile Şirketlerinde Kurumsallaşma Ve Kurumsal Yönetim Uygulamaları. İstanbul: Türkmen Kitabevi.

Azuayi R. (2016). Internationalization Strategies for Global Companies: A Case Study of Arla Foods, Denmark. Journal of Accounting \& Marketing, 5: 191. doi:10.4172/2168-9601.1000191.

Barnes, L.B., ve Hershon, S.A. (1976). Transferring power in the family business. Harvard Business Review, 54(4), 105-114.

Bernard, B. (1975). The development of organization structure in the family firm", Journal of General Management, Autumn, 42-60.

Coad, A. (2009). The growth of firms: A survey of theories and empirical evidence. Edward Elgar Publishing

Coşkun, R. ve Sancaktutan, K. (2019). Rekabet mi, İşbirliği mi? Firmaların Büyüme ve Uluslararasılaşma Kararlarında Tedarikçilerinden Beklentilerine İlişkin Nitel Bir Çalışma. Uluslararası Bilimsel Araştırmalar Dergisi (IBAD), 4(1): 21-33.

Dökümbilek, F. (2010). Aile Şirketlerinde Nepotizm ve Bir Araştırma. Yayınlanmış Yüksek Lisans Tezi. İstanbul: Bahçeşehir Üniversitesi SBE.

Erdoğmuş, N. (2007) Aile İşletmeleri: Yönetim Devri ve İkinci Kuşağın Yetiştirilmesi. 2. Baskı. İstanbul: İGİAD Yayınları. 


\section{U. S. Çitçi - T. Onur 12/1 (2020) 332-348}

Fernández, Z. ve Nieto, M. J. (2005). Internationalization Strategy of Small and Medium-Sized Family Businesses: Some İnfluential Factors. Family Business Review, 18 (1), 77-89.

Fındıkçı, I. (2005). Aile Şirketleri. 5.Baskı, İstanbul: Alfa Yayınları.

Gallo, M.A. ve García-Pont, C. (1996). Important Factors in Family Business Internationalization. Family Business Review, 9 (1), 45-59.

Gallo, M.A. ve Sveen, J. (1991). Internationalizing the Family Business: Facilitating and Restraining Forces. Family Business Review, 4, 181-190.

http://www.kobi.org.tr/

Karpuzoğlu, E. (17- 18 Nisan 2004) Aile İşletmelerinin Sürekliliğinde Kurumsallaşma. 1. Aile İşletmeleri Kongresi Bildiriler Kitabı, İstanbul Kültür Üniversitesi, 42-53.

Karpuzoğlu, E. (2002). Büyüyen ve Gelişen Aile Şirketlerinde Kurumsallaşma. İstanbul: Hayat Yayıncllık.

Koçel, T. (1993), Büyüyen İşletmelerde Karşılaşılan Yönetim ve Organizasyon Sorunları, İstanbul: İTO Yayınları.

Kutlu, H. A. ve Demirci, N. S. (2007). Kobi'lerin Finansal Sorunları ve Çözüm Önerileri. 4. KOBİler ve Verimlilik Kongresi, 187.

Leach, P., Kenway-Smith, W., Hart, A., Morris, T., Ainsworth, J., Beterlsen, E., Iraqi, S., ve Pasari, V. (1990) Managing the family business in the U.K.: A Stoy Hayward survey in conjunction with the London Business School. London: Stoy Hayward.

Lu, J.W. ve Beamish, P.W. (2006). SME internationalization and performance: Growth vs. profitability. Journal of International Entrepreneurship, 4:27-48 DOI 10.1007/s10843-006-8000-7.

Merriam, S.B. (2015). Nitel Araştırma: Desen ve Uygulama için Bir Rehber. Çev.Editörü: S. Turan. Ankara: Nobel Akademik Yayıncilik.

Morgan, G. ve Quack, S. (2005). Institutional Legacies and Firm Dynamics: The Growth and Internationalization of UK and German Law Firms. Organization Studies , 26(12): 1765-1785.

Okoroafo, S. C. (1999). Internationalization of family businesses: Evidence from Northwest Ohio, USA. Family Business Review, 12(2), 147-158.

Özler, H. ve Gümüş̧tekin, G. E. (2007). Aile İşletmelerinde Nepotizmin Gelişim Evreleri Ve Kurumsallaşma. Selçuk Üniversitesi Sosyal Bilimler Enstitüsü Dergisi, 1 (17), 437-450.

Patton, M.Q. (2014). Nitel Araştırma ve Değerlendirme Yöntemleri. Çev. M. Bütün ve Demir, S.B. Ankara: Pegem Akademi.

Peşkircioğlu, N. (2014). Aile İşletmeleri ve Kurumsallaşma. Anahtar, 312. https://anahtar.sanayi.gov.tr/tr/news/aile-isletmeleri-ve-kurumsallasma/1901 (27.01.2018).

Punch, K. F., (2016). Sosyal Araştırmalara Giriş: Nitel ve Nicel Yaklaşımlar. 4. Baskı. Ankara: Siyasal Kitabevi.

Rosenblatt, P. C., deMik, L., Anderson, R. M. ve Johnson, P. A. (1985). The family in business: Understanding and dealing with the challenges entrepreneurial families face. San Francisco: Jossey-Bass.

Rothaermel, F. T. (2015). Strategic Management. 2 nd ed., McGraw-Hill Education.

Sapienza, H. J., Autio, E., George, G. ve Zahra, S.A. (2006). A Capabilities Perspective on the Effects of Early Internationalization on Firm Survival and Growth Source. The Academy of Management Review, 31(4): 914-933.

Stenholm, P., Pukkinen, T. ve Heinonen, J. (2016). Firm Growth in Family Businesses-the Role of Entrepreneurial Orientation and the Entrepreneurial Activity. Journal of Small Business Management, 54 (2), 697-713.

Stern, M. H. (1986). Inside the family-held business. New York: Harcourt Brace Jovanovich. 


\section{U. S. Çitçi - T. Onur 12/1 (2020) 332-348}

Ulukan, C. (1999). Aile İşletmelerinde Büyüme Süreci. Yayınlanmış Doktora Tezi, Eskişehir: Anadolu Üniversitesi SBE.

Ulukan, C. (2005). Girişimcilerin ve Profesyonel Yöneticilerin Kurumsallaşma Perspektifi, Sosyal Bilimler Dergisi, 2, 29-39.

Uluyol, O. (2004). Aile Şirketleri Çatışmalar Finansal Sorunlar ve Çözümler. Medipres,78.

Ward, J. L. (1997). Growing the Family Business: Special Challenges and Best Practices. Family Business Review, $10,323-337$.

Yazıcıŏglu, İ. ve Koç, H. (2009). Aile İşletmelerinin Kurumsallaşma Düzeylerinin Belirlenmesine Yönelik Karşılaştırmalı Bir Araştırma. Selçuk Üniversitesi Sosyal Bilimler Enstitüsü Dergisi, 21, 497-507.

Yıldırım, A. ve Şimşek, H. (2018). Sosyal Bilimlerde Nitel Araştırma Yöntemleri. 11. Baskı. Ankara: Seçkin.

Zaridis, A.D. ve Mousiolis, D.T. (2014) Entrepreneurship and SME's Organizational Structure: Elements of a Successful Business. Procedia - Social and Behavioral Sciences, 148: 463 - 467. 
EK

1964- 2018 Yılları Arasındaki Aile İşletmesi Tanımları

\begin{tabular}{ccl}
\hline YIL & YAZAR & \multicolumn{1}{c}{ TANIM } \\
\hline 1964 & Donnelley & $\begin{array}{l}\text {.. bir ailenin en az iki neslinin açıça belirlenebildiği ve bu bağlantının } \\
\text { şirket politikası ile aile çıar ve hedefleri üzerinde ortak bir etkiye sahip } \\
\text { olduğu zaman... (s. 94) }\end{array}$ \\
1975 & Bernard & ...pratikte tek bir aile üyesi tarafindan kontrol edilen bir girişim... (s. 42) \\
1976 & $\begin{array}{l}\text { Barnes ve } \\
\text { Hershon }\end{array}$ & $\begin{array}{l}\text { Sahipliliğin kontrolü, bir bireyin veya tek bir ailenin üyelerinin elinde } \\
\text { olmasıdır. (s. 106) }\end{array}$
\end{tabular}
1982 Alcorn amaciyla kurulmuş... tamamı ya da bir kısmının aile tarafından yönetildiği işletmelerdir.(s. 230).

..politikaları ve yönelimleri, bir veya daha fazla aile birimi tarafından
önemli derecede etkiye maruz kalır. Bu etki sahiplenme yoluyla ve
bazen aile üyelerinin yönetime katılımıla gerçekleşmektedir (s. 47).

1985 Davis ve Tagiuri ...iki veya daha fazla aile üyesinin işin akışını etkilediği bir işletme...

\begin{tabular}{|c|c|c|}
\hline 1985 & Rosenblatt vd. & $\begin{array}{l}\text {...çoğunluğun mülkiyetinde veya kontrolünün tek bir ailenin elinde } \\
\text { olduğu ve iki veya daha fazla aile bireyinin işletmede doğrudan veya } \\
\text { dolaylı olarak yer aldığı herhangi bir işletme... (s. 4-5) }\end{array}$ \\
\hline 1986 & Pratt ve Davis & $\begin{array}{l}\text {...iki veya daha fazla aile üyesinin akrabalık bağları, yönetim rollerini } \\
\text { veya mülkiyet haklarını kullanarak işin akışını etkilemesi...( s. 2) }\end{array}$ \\
\hline 1986 & Stern & ...ailenin bir veya iki üyesi tarafından yönetilen ve işletilen... (s. 21) \\
\hline 1987 & Babicky & $\begin{array}{l}\text {...bir fikir sahibi, bir veya birkaç kişi tarafından başlatılan, girişimin } \\
\text { çoğunluk mülkiyetini korurken onu geliştirmek ve başarılı yapmak için } \\
\text { genellikle sınırlı sermayeyle büyümek için çok çalışan küçük işletme } \\
\text { türüdür (s. 25). }\end{array}$ \\
\hline 1988 & $\begin{array}{l}\text { Lansberg ve } \\
\text { Rogolsky }\end{array}$ & $\begin{array}{l}\text {...bir ailenin üyelerinin mülkiyet üzerinde yasal kontrole sahip olduğu } \\
\text { işletme... (s. 2) }\end{array}$ \\
\hline 1989 & Handler & $\begin{array}{l}\text {...lider vekâletinde başlıca işletme kararlarının ve planlarının aile } \\
\text { üyeleri ya da yönetim kurulu üyeleri tarafından belirlendiği... (s. 262) }\end{array}$ \\
\hline 1990 & Dreux & $\begin{array}{l}\text {...eylemelerinde büyük oranda yönetsel hâkimiyetin aile üyelerinden bir } \\
\text { ya da birkaçına ait olduğu girişimler... (s. 226) }\end{array}$ \\
\hline 1990 & Leach vd. & $\begin{array}{l}\text {...oy hakkının yüzde 50'den fazlasının bir aile tarafından kontrol } \\
\text { edildiği ve / veya şirketin kontrolünün tek bir aile de olduğu ve / veya } \\
\text { şirketin üst düzey yönetiminin önemli bir bölümünün aynı ailenin üyesi } \\
\text { olduğu bir şirket... }\end{array}$ \\
\hline
\end{tabular}




$1991 \quad \begin{gathered}\text { Donckels ve } \\ \text { Frohlich }\end{gathered} \quad$ Eğer aile üyeleri sermayenin en az yüzde 60'ına sahipse... (s. 152)

1991 Gallo ve Sveen …hisselerin çoğunluğuna tek bir ailenin sahip olduğu ve tüm kontrolün tek bir ailede toplandiğ $1 . .$. (s. 181)

$\begin{array}{ccc} & & \begin{array}{l}\text { Mülkiyetin tamamen aile üyelerinin elinde olduğu, en az bir aile } \\ \text { üyesinin ya işyerinde istihdam edildiği ya da resmi olarak aile üyeleri } \\ \text { çalışmasa da dişarıdan işletmeye müdahalede bulunabildiği } \\ \text { işletmelerdir. (s. 304) }\end{array} \\ 1991 \quad \text { Lyman } & \begin{array}{c}\text { Holland ve } \\ \text { Oliver }\end{array} & \begin{array}{l}\text {...mülkiyet veya yönetimle ilgili kararların bir aileden veya ailelerle olan } \\ \text { ilişkilerden etkilendiği işletmeler...(s. 27) }\end{array}\end{array}$

$1993 \begin{array}{cl}\text { Churchill ve } & \text {...görece yaşlı aile üyesinden işin kontrolünü üstüne alacak ya da } \\ \text { sahiplenecek görece daha genç bir aile üyesinin yetişmesini veya o işe } \\ \text { katılmasını bekleyen işletmeler... (s. 52) }\end{array}$

$1993 \quad$ Welsch $\quad$...sahiplerden birinin yönettiği ve sahiplerinin veya sahiplerinin akrabalarının yönetim sürecine dâhil olduğu...(s.40)

$1994 \quad$ Carsrud $\quad \begin{aligned} & \text {..sıkı takip edilen firmanın sahipliği ve politikaların belirlenmesi } \\ & \text { "duygusal akrabalık" ilişkisinin olduğu üyeler tarafından yönetilen } \\ & \text { işletmelerdir. (s.40) }\end{aligned}$

1995 Litz ...aile üyelerinden biri ya da birkaçı tarafından kurulmuş, işletmenin idaresinin, varlıklarının, ortaklıkların genellikle aile bireylerinden oluştuğu...(s. 71).

$\begin{array}{ll}1996 & \begin{array}{l}\text { Shanker ve } \\ \text { Astrachan }\end{array} \\ & \begin{array}{l}\text { buletmenin sahipliğinin ve mevcut yönetiminin ailenin elinde } \\ \text { olduğu ve farklı kuşakların aktif olarak yönetimde rol aldığı } \\ \text { işletmelerdir. }\end{array}\end{array}$

1997 Sharma, ...kamuya açık firmalara kıyasla, aile üyeleri tarafından yakından takip Chrisman ve edilen, ailenin mülkiyetinde olan şirketler...

Chua
1998 Neubauer ve _.. sermayesinin hatırı sayılır bir payının belli bir aileye ait olduğu, aile Lank üyelerinin, yöneticilik ve bunun gibi diğer önemli pozisyonlarda istihdam edildiği işletmelerdir. (s.5)

2003 Miller, Steier ve İşletme aile tarafından kontrol edilmektedir.

Le Breton

2005 Murphy $\quad \begin{aligned} & \text { Sadece aile üyelerinin katıldı̆̆ı ve stratejik yönetim kararlarının ailenin } \\ & \text { elinde olduğu birkaç kuşağı içeren yapılardır. }\end{aligned}$

$2006 \quad$ Lee $\quad$...mülkiyeti ve yönetimi aile elinde bulundurur...

2007 Martinez, Stohr Sahipliği açıkça aile tarafından kontrol edilen kuşaktan kuşağa ve Quiroga devredilen işletmeler... 


\begin{tabular}{|c|c|c|}
\hline 2008 & $\begin{array}{l}\text { Zahra ve } \\
\text { diğerleri }\end{array}$ & $\begin{array}{l}\text {...aile firmaları genellikle benzersiz özelliklere ve kaynaklara sahiptirler. } \\
\text { Bu da, aile işletmesi olmayan firmalara kıyasla rekabet avantajı } \\
\text { sağlamaktadır. }\end{array}$ \\
\hline 2011 & Chua vd. & ...ailenin finansal kararlara doğrudan ya da dolaylı dahil olduğu... \\
\hline 2012 & Gedajlovic vd. & ...aile üyeleri karar alma sürecinde stratejik olarak rol almaktadır. \\
\hline 2013 & $\begin{array}{l}\text { Kotlar ve De } \\
\text { Massis }\end{array}$ & ...ailenin yönetimde egemen olduğu... \\
\hline 2014 & Cruz vd. & $\begin{array}{l}\text {...işletmenin kurumsal itibarının önemli olduğu ve paydaşların } \\
\text { taleplerinin önemsendiği... }\end{array}$ \\
\hline 2015 & $\begin{array}{l}\text { Jaskiewicz, } \\
\text { Combs ve Rau }\end{array}$ & ...sahipliğin ve kontrolün ailenin kontrolünde olduğu işletmeler... \\
\hline 2016 & $\begin{array}{l}\text { Gu, Lu ve } \\
\text { Chung }\end{array}$ & ...ailenin kontrolünde olan işletmelerdir. \\
\hline 2017 & Arregle vd. & $\begin{array}{l}\text {...yönetimde hızlı karar alabilen, esnek, uzun vadeli hedefleri olan } \\
\text { işletmelerdir. }\end{array}$ \\
\hline 2018 & Zahra & ...girişimci risk almaktadır. Mülkiyetin ailenin elinde olduğu... \\
\hline
\end{tabular}

